\title{
Revisit the Budget Deficits and Inflation: Evidence from Time and Frequency Domain Analyses
}

\author{
Aviral Kumar Tiwari'1, Süleyman Bolat ${ }^{2 *}$, Özgür Koçbulut ${ }^{3}$ \\ ${ }^{1}$ Faculty of Management, IBS/IFHE Hyderabad, Hyderabad, India \\ ${ }^{2}$ Department of Public Finance, Faculty of Economics and Administrative Sciences, Aksaray University, Aksaray, \\ Turkey \\ ${ }^{3}$ Department of Accounting and Tax Applications, Akdağmadeni Vocational High School, Bozok University, \\ Yozgat, Turkey \\ Email: aviral.eco@gmail.com, ${ }^{*}$ bolatsuleyman80@gmail.com, o.kocbulut@gmail.com
}

Received 13 April 2015; accepted 6 May 2015; published 8 May 2015

Copyright (C) 2015 by authors and Scientific Research Publishing Inc.

This work is licensed under the Creative Commons Attribution International License (CC BY).

http://creativecommons.org/licenses/by/4.0/

(c) (i) Open Access

\begin{abstract}
The purpose of this paper is to test the relationship between budget deficits and inflation for nine EU countries during the period of 1990-2013 using the quarterly data. Recently, the public deficits and inflation have had an increasing importance for developing/emerging and developed countries to build the stability macroeconomic performance in the long run. This study is the first attempt to determine the relationship between the inflation and budget deficits for nine EU countries using different bootstrap causality tests. We employ the bootstrap causality and Granger causality test in the frequency domain analysis which allows us to distinguish short and long-run causality. We do not find a relationship between these variables when we employ bootstrap causality analysis. While the frequency domain causality shows that there is no relationship causality from budget deficits to inflation for all countries, causality from inflation to budget deficits indicates a permanent (long-run) relationship for Belgium, and France.
\end{abstract}

\section{Keywords}

Budget Deficits, Inflation, Frequency Domain Analysis, EU Countries

\section{Introduction}

There is a growing body of the literature which examines the relationships between the budget deficits and infla-

"Corresponding author.

How to cite this paper: Tiwari, A.K., Bolat, S. and Koçbulut, Ö. (2015) Revisit the Budget Deficits and Inflation: Evidence from Time and Frequency Domain Analyses. Theoretical Economics Letters, 5, 357-369. 
tion using different methods. Not only researchers but also policymakers take interest in this topic and it is also important for monetary policy and macroeconomics area. There is a wide range of theory about the inflation and budget deficits in the economic literature. In the light of theoretical discussions, the one of the well-organized works in this area was made by Sargent and Wallace [1]. They maintain that monetary policy can not permanently control the inflation. If the monetary policy dominates the fiscal policy, monetary policy independently can set itself. So, monetary authorities can determine the amount of revenue which supplies to fiscal authority by seignorage. Any deficits of public area can be financed bond sale to the public and seignorage combination proposed by monetary authority. Under this condition, monetary authority can control the inflation, because they dominate the base money for current and future periods and choose to free. If the fiscal policy dominates the monetary policy, fiscal authorities set its budget position with the amount of revenue determining the new bond sales and seignorage. Therefore, monetary authority faces the constraint by the demand of government bonds. Due to gap between the revenue from demanded government and a number of bonds to public, governments run to monetize its deficits and monetary authority is forced to create additional money for government. They suggest that there is a correlation between the inflation and budget deficits. Fiscal dimension of inflation has been an increasing substantial in developing and emerging countries.

According to Tanzi [2], there is a relationship between inflation and budget deficit. When the rate of inflation increases, the inflation tax will create more and more revenue. Then, when the inflation rate expands, the ratio of tax revenue to national income will decrease and consequently inflation will cause a deficit. Due to the lags in the tax collection, the tax revenues of a country can be limited and this situation makes deficit financing difficult. The first reason of this stems from the price elasticity of the tax system. If the elasticity is low, lags in the tax collection will be impressed largely. The second reason is the tax revenue to GDP, namely tax burden. If the lags in tax collection increase, total tax revenue will diminish during the inflation period. The third reason is financed by money creation of central banks in order to avoid the impact of a fall in revenue. The fourth reason is the elasticity of demand in real balances relative to expected inflation, and consequently, the effects of inflation on the deficit will be greater.

Catão and Terrones [3] assumed that emerging/developing countries have low capacity of tax collection, political and economic stabilities, fiscal imbalances, high inflation and limited access to external debts. Therefore, they tend towards the lower costs of seigniorage and this situation causes inflation tax in these countries (see, Alesina and Drazen [4]; Cukierman [5]; Jalil, Tariq and Bibi [6]). So, Catão and Terrones [3] offered an intertemporal optimization model which is used to display equilibrium inflation. Equilibrium inflation is also interested in fiscal deficits scaled by narrow money, where the latter stands for the size of the inflation tax base. Sargent and Wallace [1] assumed that Ricardian regime can be determined as regime of monetary predominance, if money demand and supply determine in this price level. Besides, non-Ricardian regime is also labelled as regime of fiscal predominance. These prices would be determined from the government budget constraint endogenously. The classifications of Ricardian and non-Ricardian regimes were done by Aiyagari and Gertler [7].

In the literature, as a result of government expenditure increase, expansionary fiscal policy appears and this result increases aggregate demand and goes up the inflation. This theory agrees with both classical and Keynesian economic school. Ricardian equivalence hypothesis, which is supported by classical economic thought, argues that budget deficits neither affect aggregate demand nor cause inflation due to cut in taxes. But Keynesian view supports the non-Ricardian regime in which tax cut goes up the aggregate demand and inflation. On the other hand, Ricardian regime shows that monetary authority has an "active behavior"; treasury has a "passive behaviour". The fiscal theory of price level (FTPL) developed by Leeper [8] ${ }^{1}$, Sims [9] and Woodford [10]-[12] is often used in the economic literature. The main purpose of this study can determine the price level with fiscal policy or monetary policy. FTPL theory suggests that the price level is determined through the inter-temporal government budget constraint.

The contribution of our empirical study is quart. Firstly, unlike previous time series studies, we examine the relationship between the budget deficits and inflation for 9 countries as a time series. So, we can fulfill a need in this area. We can compare different results of these countries for causality. Secondly, we test both frequency domain causality and the Toda and Yamamoto [21] procedure and bootstrapped causality suggested by Hacker and Hatemi-J [22] methods. Therefore, we can give insight about these topics by comparison of analysis results. Thirdly, fiscal deficits and inflation are tested by employing the frequency domain in terms of short and long-

${ }^{1}$ Some examples of FTPL is given by Woodford [13], Cochrane [14] [15]. Other hand, some papers about international framework are also examined by Dupor [16], Bergin [17], Canzoneri, Cumby and Diba [18], Daniel [19] and Sims [20]. 
run causality. By doing so, this paper is the first time to examine between these variables in low and high frequencies. Fourthly, this study employs lag order selection supposed by Hannan and Quinn [23] information criterion (HQC) and Hatemi-J [24] Criteria (HJC). The rest of the paper is organized as follows. Section 2 includes literature review, and then Section 3 introduces the data and methodology. In Section 4, we discuss the empirical results and the robustness check. Finally Section 5 concludes in this paper.

\section{Literature Review}

There is growing literature about the fiscal deficits and inflation. In this area, there have been plenty of studies in relationship between fiscal deficits and inflation in this literature, still no consensus is reached. In the light of theoretical discussions, first works in this area were made by Sargent and Wallace [1]. They examine monetary and fiscal dominance regimes on the discussion between the inflation and budget deficits. According to them, when the monetary policy dominates the fiscal policy, monetary authority can independently determine the monetary policy. Therefore, budget deficits are determined with bond sales to the public and provide seignorage from monetary authority. Thereby, fiscal policy authority meets with a budget constraint enforced by monetary. This mechanism will control the inflation process, then budget deficits do not cause to inflation. When the fiscal authority is more dominant then the monetary authority, the monetary does not avoid the inflation process and this situation goes up the inflation mechanism.

There is also empirical relationship between budget deficits and inflation for both developed and developing countries. Empirical studies show statistically significant connection between fiscal deficits and inflation in economic literature. It has been growing literature in this area and most papers in these topics focus on the comprehensive examination of the relationship between fiscal deficits and inflation. The main purpose of this analysis can understand the determiners of the inflation. There are some studies for the US (Hamburger and Zwick [25]; Dwyer [26]; Darrat [27]; Ahking and Miller [28]) and the others are related to developed countries (King and Plosser [29]; Giannaros and Kolluri [30]; Protopapadakis and Siegel [31]; Barnhart and Darrat [32]). About these topics, there are lots of papers for some other countries (Ho [33]; Siddiqui [34]; Burdekin and Wohar [35]; De Haan and Zelhorst [36]; Choudhary and Parai [37]; Buiter and Patel [38]; Dogas [39]; Sowa [40]; Hondroyiannis and Papapetrou [41] Metin [42]; Metin [43]; Domac and Yucel [44]; Lin and Chu [45]; Jalil, Tariq and Bibi [6]).

There are too empirical studies in the relationship between budget deficits and inflation. Hamburger and Zwick [25] tested the relationships between monetary and fiscal policy in the US. They found that deficits had had important effect on the growth in the US money supply since 1961. The effects of the deficits on the inflation are stronger in 1961-1974. In the next year, Dwyer [26] examined relationship among debt, price, and money as quarterly data from 1953 to 1978 . He finds that there is no evidence, so debt plays an important role for determining the price level and money stock. Ahking and Miller [28] also test the relationship among deficits, money growth and inflation in the United States for 1947-1980. They found that there was a relationship government between deficit and inflation for 1950's and 1970's. Darrat [27] examines the potential relationship between federal budget deficits and inflation after 1960 in the US. The results show that monetary growth and federal deficits have significant effects on inflation along 1960s and 1970s.

King and Plosser [29] examine the government deficits and factors which affect the inflation in terms of neoclassical macroeconomic models in the post-war period for the United States. They found that it is difficult to determine the inflationary effects of the deficits in the post-war period in the US and other countries during 1953-1982. Other hand, they also test this relationship in 12 industrial and developing countries, namely UK, France, West Germany, Italy, Japan, Spain, Argentina, Brazil, Chile, Mexico and Korea. They do not find the connection between inflation and deficits for 12 countries. Moreover, Giannaros and Kolluri [30] test the relationship between government deficits and the money growth or the rate of inflation for majority of 10 industrialized countries (US, Canada, Japan, UK, West Germany, France, Italy, Netherlands, and Belgium) during the period 1950 to 1981. These results show that the fiscal deficits do not increase the money supply and the inflation rate. Protopapadakis and Siegel [31] test the relation between the government debt growth, money growth and inflation for ten industrialized countries during the period 1952-1987. Test results display that there is no significant association between increases in debt growth and money growth. That is, this relationship is weak between them. Barnhart and Darrat [32] investigate the causal linkage between money growth and budget deficits for G-7 countries covering period 1960-1984 as a quarterly. Their results reject this hypothesis, which 
budget deficits have caused a positive long-run effect on the money growth, for all seven countries and the results of reverse hypothesis are same. Generally, monetary and fiscal policies for G-7 countries are independent. De Haan and Zelhorst [36] examine the connection between government budget deficits and money growth in 17 developing countries covering period 1961-1985. Their results do not support the hypothesis which deficits affect money growth. Shabbir, Ahmed and Ali [46] focus on analyze to the direct and indirect effects of budget deficit on inflation for the period 1971-1972 and 1987-1988 in Pakistan. The findings of this paper are that budget deficits have a positive and significant direct effect on inflation. Hondroyiannis and Papapetrou [41] investigate the relationship between the government budget and inflation in Greece for the period 1960-1992. Empirical evidence shows that there is a long-run relationship between government budget and price level. These empirical findings support the hypothesis of bidirectional causality between the two variables in Greek economy. Karras [47] examines the effects of budget deficits on money growth, inflation, and investment and real output growth for 32 countries covering the period 1950-1989. The empirical findings show that deficits do not produce inflation via monetary expansions and deficits negatively affect the rate of growth of real output. Metin [42] analyzed the inflationary process in Turkey the period from 1950 to 1988. She found that fiscal expansion dominated the determination of inflation. Therefore, the excess demand for money affected positively inflation in the short-run. Other hand, Metin [43] examines the relationship between inflation and budget deficit in Turkey using cointegration analysis during the period of 1950-1987. Results show that budget deficits importantly affect inflation in Turkey.

Cottarelli, Griffiths and Moghadam [48] test inflation performance for 47 industrial and transition countries covering period 1993-1996. They suggest that fiscal deficits have an important role on the inflation for these countries. Thus, Komulainen and Pirttilä [49] investigate the price stability for three transition economies (Bulgaria, Romania and Russia) using vector-autoregressive models. Empirical evidences indicate that fiscal deficits have an important role on the inflation in Bulgaria and Romania except for Russia. Neyapti [50] tests whether there is a relationship between budget deficits and inflation for 54 developed and less developed countries over the period of 1970-1989. Test results advance that budget deficits have a positive effect on the inflation for these countries. Domac and Yucel [44] examine the factors of inflation with pooled probit analysis for 15 emerging markets in the period from 1980 to 2001. Paper findings show that output gap, agricultural shocks and expansionary fiscal policies are efficient on the inflation in these countries. Catão and Terrones [3] examine inflation as non-linearly related to fiscal deficits. They try to determine between short and long-run effects of fiscal deficits for 107 countries over the period 1960-2001. Empirical results display that there is strong relationship between inflation and deficits for developing and high inflation country groups except low-inflation and developed economies. Tiwari, Tiwari and Pandey [51] examine the direction of causality among public expenditure, money supply, fiscal deficits and inflation using Dolado and Lutkepol (DL) and standard Granger causality approach for India in the period 1971-2009. They suggest that inflation is not Granger-cause fiscal deficit in the model. Lin and Chu [45] investigate the relationship between inflation and deficits in 91 countries during the period 1960 to 2006 with dynamic panel quantile regression model under the autoregressive distributional lag (ARDL) specification. Empirical results indicate that fiscal deficit has a strong effect on the inflation in the high-inflation events, but it is weak in the low-inflation episodes. Jalil, Tariq and Bibi [6] also test the inflation and fiscal deficit for Pakistan during the period 1972 to 2012. They suggest that there is a positive relationship between fiscal deficit and inflation.

\section{Data and Methodology}

The purpose of this paper is to test whether there is a relationship between budget deficits and inflation by using two methodological ways for nine countries for period from 1990 to 2013 using a quarterly data. These countries have been selected according to the data availability. The data is drawn from the Eurostat Database and IMF International Financial Statistics (IFS). Countries and time spans used in this analysis are shown in Table 1. Owing to data unavailability, we used different data spans that are presented in Table 1. In order to make a comparison for our study, we will use both Hacker and Hatemi-J causality test and the frequency domain test. Our empirical analysis covers these variables for nine countries, namely Belgium, Cyprus, France, Germany, Netherlands, Spain, Sweden and UK. The seasonally adjusted series for these variables were completed by using the Census X-12 procedure. 
Table 1. Country classifications.

\begin{tabular}{cccc}
\hline Countries & Time span & Countries & Time Span \\
\hline Belgium & 1991Q1-2013Q1 & Spain & 1995Q1-2013Q1 \\
Cyprus & 1995Q1-2013Q1 & Sweden & 1993Q1-2013Q1 \\
France & 1991Q1-2012Q4 & UK & 1990Q1-2013Q1 \\
Germany & 1995Q1-2012Q4 & \\
Netherlands & 1991Q1-2013Q1 & \\
\hline
\end{tabular}

\subsection{Causality Analysis in the Time Domain}

In the Granger-causality literature for time series data there are several tests developed such as Engle-Granger approach, Sim's causality approach, VAR Granger-causality approach, and last but not least Toda and Yamamoto (TY, [21]) approach. In our estimation, we utilized TY approach with bootstrap procedure suggested in Hacker and Hatemi-J [22] methods. The advantages of this approach are well known in the literature, such as, this approach does not require pre-testing of unit root and cointegration (i.e., TY method offers an approach for the estimation of VAR process for series in levels, even if the series are integrated or cointegrated) and it is robust when VAR processes may have some unit roots (Toda and Yamamoto [21]). The estimation process is explained briefly as follows.

1) Determine the optimal order of the VAR process $(p)$.

2) Determine the maximal order of integration occurring in the true generation process for variables.

3) Estimate the augmented VAR $(p+d m a x)$ model, where dmax is the maximal order of integration of variables determined in step 2.

4) Test Granger-causality by utilizing modified Wald (MWALD) test in an estimated augmented VAR model in step 3.

Say following is a augmented VAR $(p+d m a x)$ model to be estimated:

$$
Y_{t}=\hat{\lambda}+\hat{\Theta}_{1} x_{t-1}+\cdots+\hat{\Theta}_{p} Y_{t-p}+\hat{\Theta}_{p+d} X_{t-p-d}+\hat{\xi}_{t}
$$

where the circumflex above a variable denotes its Ordinary Least Square (OLS) estimates and the $d$ is the maximal order of integration of the variables. Following Hacker and Hatemi-J [22] the Wald test for a sample size of $T$ can be explained as follows:

$$
\begin{gathered}
L=\left(x_{1}, \cdots, x_{T}\right) \quad(n \times T) \text { matrix, } \\
\hat{K}=\left(\hat{\mu}, \hat{\Theta}_{1}, \cdots, \hat{\Theta}_{p}, \hat{\Theta}_{p+d}\right) \quad(n \times(1+n(p+d))) \text { matrix } \\
Z_{t}=\left[\begin{array}{c}
1 \\
x_{t} \\
x_{t-1} \\
\vdots \\
x_{t-p-d+1}
\end{array}\right] \quad((1+n(p+d)) \times 1) \text { matrix, for } t=1, \cdots, T \\
Z=\left(Z_{0}, \cdots, Z_{t-1}\right) \quad((1+n(p+d)) \times T) \text { matrix , and } \varsigma=\left(\xi_{1}, \cdots, \xi_{T}\right) \quad(n \times T) \text { matrix. }
\end{gathered}
$$

Using these notations, the estimated $\operatorname{VAR}(p+d)$ model will be as follows:

$$
L=K Z+\varsigma
$$

To test for the non-Granger causality the MWALD test developed by Toda and Yamamoto [21] may be defined as follows:

$$
\text { MWALD }=(C \hat{\beta})^{\prime}\left[C\left(\left(Z^{\prime} Z\right)^{-1} \otimes S_{U}\right) C^{\prime}\right]^{-1}(C \hat{\beta})
$$

where $\otimes$ is the kronecker product, $C$ is a $p \times n(1+n(p+d))$ matrix, $S_{U}$ is the estimated variance-cova- 
riance matrix of residuals in Equation (2), when the null hypothesis of non-Granger causality is not placed, $\beta$ is $\operatorname{vec}(D)$, vec shows the column-stacking operator. When MWALD test statistic is asymptotically $\chi^{2}$ distributed by the number of degrees of freedom equal to $p$, the number of restrictions is tested under the estimation (Hacker and Hatemi-J [22]; Hatemi-J and Morgan [52]). Furthermore, Hacker and Hatemi-J [22] revealed that the MWALD test statistics declines the null hypothesis, when the data generating process for the error terms is characterized with non-normality and existing of autoregressive conditional heteroscedasticity (ARCH) by Monte Carlo Simulations. Thus, they proposed a leveraged bootstrap simulation technique to overcome such situation. Moreover, the lag-section in the study is based on the information criterion introduced by Hatemi-J [24] which could be defined as follows:

$$
H J C=\ln \left(\operatorname{det} \hat{\Omega}_{j}\right)+j\left(\frac{n^{2} \ln T+2 n^{2} \ln (\ln T)}{2 T}\right), j=0, \cdots, p
$$

where $\operatorname{det} \hat{\Omega}_{j}$ is determinant of the evaluated variance-covariance matrix of the error terms in the VAR model for lag order $j, T$ is the number of observations used to estimate the VAR model and finally $n$ is the number of variables in Equation (4).

\subsection{Causality Analysis in the Frequency Domain}

Granger [53] was the first study to give the idea about spectral-density approach to test for Granger-causality (GC) which was further elaborated in Geweke [54]. Recently, Breitung and Candelon [55] proposed approach to test GC in the frequency domain taking idea from Granger [53] and Geweke [54]. The procedure of Breitung and Candelon [56]. GC approach could be explained as follows:

Let $Y_{t}=\left[\operatorname{Inf}_{t}, B D_{t}\right]^{\prime}$ be a two-dimensional vector of time series (inflation and budget deficit respectively) observed at $t=1, \cdots, T$ and it has a finite-order VAR representation of the form

$$
\Theta(L) Y_{t}=\xi_{t}
$$

where, $\Theta(L)=I-\Theta_{1} L-\cdots-\Theta_{p} L^{p}$ is a $2 \times 2$ lag polynomial with $L^{k} Y_{t}=Y_{t-k}$. We assume that the error vector $\xi_{t}$ is white noise with $E\left(\xi_{t}\right)=0$ and $E\left(\xi_{t} \xi_{t}^{\prime}\right)=\Sigma$, ; where $\Sigma$ is positive definite. For ease of exposition we neglect any deterministic terms in (1).

Let $G$ be the lower triangular matrix of the Cholesky decomposition $G^{\prime} G=\Sigma^{-1}$ such that $E\left(\eta_{t} \eta_{t}^{\prime}\right)=I$ and $\eta_{t}=G \xi_{t}$. If the system is assumed to be stationary, the MA representation of the system is

$$
\begin{aligned}
& Y_{t}=\Phi(L) \xi_{t}=\left[\begin{array}{ll}
\Phi_{11}(L) & \Phi_{12}(L) \\
\Phi_{21}(L) & \Phi_{22}(L)
\end{array}\right]\left[\begin{array}{l}
\xi_{1 t} \\
\xi_{2 t}
\end{array}\right] \\
& =\Psi(L) \eta_{t}=\left[\begin{array}{ll}
\Psi_{11}(L) & \Psi_{12}(L) \\
\Psi_{21}(L) & \Psi_{22}(L)
\end{array}\right]\left[\begin{array}{l}
\eta_{1 t} \\
\eta_{2 t}
\end{array}\right]
\end{aligned}
$$

where $\Phi(L)=\Theta(L)^{-1}$ and $\Psi(L)=\Phi(L) G^{-1}$. Using this representation the spectral density of $F_{t}$ can be expressed as

$$
f_{\text {Inf }}(\omega)=\frac{1}{2 \pi}\left\{\left|\Psi_{11}\left(\mathrm{e}^{-i \omega}\right)\right|^{2}+\left|\Psi_{12}\left(\mathrm{e}^{-i \omega}\right)\right|^{2}\right\} .
$$

The measure of causality suggested by Geweke [54] is defined as

$$
\begin{gathered}
M_{B D \rightarrow \operatorname{Inf}}(\omega)=\log \left[\frac{2 \pi f_{\text {Inf }}(\omega)}{\left|\Psi_{11}\left(\mathrm{e}^{-i \omega}\right)\right|^{2}}\right] \\
=\log \mid 1+\frac{\left|\Psi_{12}\left(\mathrm{e}^{-i \omega}\right)\right|}{\left|\Psi_{11}\left(\mathrm{e}^{-i \omega}\right)\right|} .
\end{gathered}
$$

If $\left|\psi_{12}\left(\mathrm{e}^{-i \omega}\right)\right|^{2}=0$, then the Geweke's measure will be zero, then $B D$ will not Granger cause INF at fre- 
quency $\omega$. If the elements of $Y_{t}$ are $I(1)$ and co-integrated, in that case in the frequency domain the measure of causality can be defined by using the orthogonalized MA representation

$$
\Delta Y_{t}=\tilde{\Phi}(L) \xi_{t}=\tilde{\Psi}(L) \eta_{t},
$$

where $\tilde{\Psi}(L)=\tilde{\Phi}(L) G^{-1}, \eta_{t}=G \xi_{t}$, and $G$ is a lower triangular matrix such that $E\left(\eta_{t} \eta_{t}^{\prime}\right)=I$. Note that in a bivariate co-integrated system $\beta^{\prime} \tilde{\Psi}(1)=0$, where $\beta$ is a co-integration vector such that $\beta^{\prime} Y_{t}$ is stationary (Engle and Granger [56]). As in the stationary case the resulting causality measure is

$$
M_{B D \rightarrow \operatorname{Inf}}(\omega)=\log \mid 1+\frac{\mid \tilde{\Psi}_{12}\left(\mathrm{e}^{-i \omega}\right)}{\left|\tilde{\Psi}_{11}\left(\mathrm{e}^{-i \omega}\right)\right|} .
$$

To test the hypothesis that $B D$ does not cause Inf at frequency $\omega$ we consider the null Hypothesis

$$
M_{B D \rightarrow I n f}(\omega)=0
$$

within a bivariate framework. Breitung and Candelon [55] present this test by reformulating the relationship between Inf and BD in VAR equation:

$$
I n f_{t}=a_{1} I n f_{t-1}+\cdots+a_{p} I n f_{t-p}+\beta_{1} B D_{t-1}+\cdots+\beta_{p} B D_{t-p}+\zeta_{1 t}
$$

The null hypothesis tested by Geweke, $M_{B D \rightarrow \operatorname{lnf}}(\omega)=0$, corresponds to the null hypothesis of

$$
H_{0}: R(\omega) \beta=0
$$

where $\beta$ is the vector of the coefficients of $B D$ and

$$
R(\omega)=\left[\begin{array}{c}
\cos (\omega) \cos (2 \omega) \cdots \cos (p \omega) \\
\sin (\omega) \sin (2 \omega) \cdots \sin (p \omega)
\end{array}\right]
$$

The ordinary $F$ statistic for (15) is approximately distributed as $F(2, T-2 p)$ for $\omega \in(0, \pi)$. It is interesting to consider the frequency domain causality test within a co-integrating framework. To this end Breitung and Candelon [55] suggested to replace $F_{t}$ in regression (14) by $\Delta \operatorname{Inf} f_{t}$, with the right-hand side of the equation remaining the same (see Breitung and Candelon [55]) for more detailed discussion on this and for the case when one variable is $I(1)$ and other is $I(0)$. Furthermore, it is important to mention that in co-integrated systems the definition of causality at frequency zero is equivalent to the concept of "long-run causality" and in stationary framework there exists no long-run relationship between time series, a series may nevertheless explain future low frequency variation of another time series. Hence, in a stationary system, causality at low frequencies implies that the additional variable is able to forecast the low frequency component of the variable of interest on one period ahead.

\section{Empirical Results}

This paper is to examine literature by extending the relationship between the budget deficits and inflation. The contribution of this study is to investigate in two methodological ways for nine countries for period from 1990 to 2013. At first, we will employ both the Toda-Yamamoto method based on asymptotic critical values and the bootstrap corrected causality test suggested by Hacker and Hatemi-J [22] method. Empirical analysis is composed of several steps about first method. We will determine maximum integration order for our variables, because Toda-Yamamoto procedure needs additional lag. In order to determine our dataset which is inflation and budget deficit, we use some unit root tests including Phillips and Perron [57] (henceforth, PP) test and the Kwiatkowski, Phillips, Schmidt and Shin [58] (henceforth, KPPS) tests. Then, we will choose optimal lag order using Monte Carlo simulation in the VAR models. Herewith, we illustrate different information criteria which are Akaike Information Criteria (AIC), Hannan-Quinn Criteria (HQC), Schwarz Bayesian Information Criteria (SBC), Hatemi-J Criteria (HJC). The next step of this analysis is to run the causality test between inflation and fiscal deficit using Hacker and Hatemi-J [22]. As a second method in this study, we use the Granger causality test in the frequency domain introduced by Breitung and Candelon [55].

Before analyzing causality between the budget deficits and inflation, we have to determine maximum integration order of variables. So, the Toda-Yamamoto procedure needs the additional lag(s) in terms of determining 
the maximum integration degree of our variables. In order to ensure reliability for our variables, we use several unit root tests developed by PP and the KPPS test. Table 2 reports the results of these unit root tests. The results show that PP and KPSS tests do not reject the null hypothesis for the levels of the budget deficit and inflation in some countries.

We will choose optimal lag order using Monte Carlo simulation in the VAR models. Herewith, we illustrate different information criteria which are Akaike Information Criteria (AIC), Hannan-Quinn Criteria (HQC), Schwarz Bayesian Information Criteria (SBC), Hatemi-J Criteria (HJC) in Table 3. We use same lag length for France, Germany, Netherlands, Spain, Sweden except for Belgium, Cyprus and UK.

Table 4 shows the results of the TY procedure [21] and the bootstrap-corrected causality test developed by Hacker and Hatemi-J [22]. In order to test the causal relationship between inflation and budget deficits, we analyzed our variables using the Toda and Yamamoto [21] procedure and bootstrapped causality suggested by Hacker and Hatemi-J [22] methods based on Toda-Yamamoto [21] linear Granger causality analysis in Table 4. We use Hatemi-J information criteria (HJC) in Table 4. While TY probability values were based on the significance levels of MWALD statistics, MWALD test statistics were compared to $1 \%, 5 \%$ and $10 \%$ bootstrap critical values. According to the results, the TY and the Hacker and Hatemi-J causality tests show the same results. Empirical test results indicate that there is no causality between budget deficits and inflation. Results of both procedures present that null hypothesis of no Granger causality for these variables are accepted at $1 \%, 5 \%$ and 10\% significance levels in Table 4.

It is important to determine the selection of lag length for correct results in our analysis. In our analysis, we

Table 2. Results of unit root tests.

\begin{tabular}{|c|c|c|c|c|}
\hline \multirow{2}{*}{ Countries } & \multicolumn{2}{|c|}{ Budget Deficit } & \multicolumn{2}{|c|}{ Inflation } \\
\hline & PP & KPSS & PP & KPSS \\
\hline Belgium & $-3.70^{* *}$ & $0.31^{* * *}$ & $-3.89^{* *}$ & 0.10 \\
\hline Cyprus & $-4.51^{* *}$ & 0.09 & $-4.27^{* * *}$ & 0.03 \\
\hline France & -2.59 & $0.19^{* * *}$ & $-3.47^{* *}$ & $0.13^{*}$ \\
\hline Germany & $-9.72^{* * *}$ & 0.09 & $-3.38^{*}$ & 0.04 \\
\hline Netherlands & -1.84 & $0.24^{* * *}$ & -2.66 & 0.07 \\
\hline Spain & -2.06 & $0.19^{* *}$ & -2.37 & 0.09 \\
\hline Sweden & -1.71 & $0.24^{* * *}$ & -2.52 & 0.07 \\
\hline UK & -2.19 & $0.19^{* *}$ & -2.06 & $0.26^{* * * *}$ \\
\hline
\end{tabular}

Notes: The critical values for PP test are $-4.07,-3.46$ and 3.16 and the critical values for KPSS test are $0.22,0.15$ and 0.12 at $1 \%, 5 \%$ and $10 \%$ significance level, respectively. ${ }^{* * *}{ }^{* *}{ }^{*}$ and ${ }^{*}$ show the rejection of the null hypothesis at $1 \%, 5 \%$ and $10 \%$ significance level, respectively.

Table 3. Optimal lag selection.

\begin{tabular}{ccccc}
\hline Countries & AIC & SBC & HQC & HJC \\
\hline Belgium & {$[3](2.234)$} & {$[2](6.128)$} & {$[3](5.947)$} & {$[2](6.043)$} \\
Cyprus & {$[2](3.986)$} & {$[1](7.837)$} & {$[2](7.654)$} & {$[2](7.752)$} \\
France & {$[2](-0.087)$} & {$[2](3.774)$} & {$[2](3.601)$} & {$[2](3.688)$} \\
Germany & {$[1](2.686)$} & {$[1](6.444)$} & {$[1](6.326)$} & {$[1](6.385)$} \\
Netherlands & {$[1](2.597)$} & {$[1](6.359)$} & {$[1](6.256)$} & {$[1](6.307)$} \\
Spain & {$[1](2.650)$} & {$[1](6.408)$} & {$[1](6.291)$} & {$[1](6.349)$} \\
Sweden & {$[1](1.142)$} & {$[1](4.902)$} & {$[1](4.793)$} & {$[1](4.848)$} \\
UK & {$[2](1.766)$} & {$[1](5.580)$} & {$[2](5.458)$} & {$[1](5.530)$} \\
\hline
\end{tabular}

Notes: Akaike Information Criteria (AIC), Hannan-Quinn Criteria (HQC), Schwarz Bayesian Information Criteria (SBC), Hatemi-J Criteria (HJC). The numbers in brackets are the optimal lag lengths and minimum test statistics are in the parenthesis. 
chose four different information criteria², namely Akaike Information Criteria (AIC), Hannan-Quinn Criteria (HQC), Schwarz Bayesian Information Criteria (SBC), Hatemi-J Criteria (HJC). It is shown two different lag length selected by HJC and HQC to test between our variables in Table 4 and Table 5 . The causality test results are represented in Table 5 based on HQC. In order to test the causal relationship between inflation and budget deficits, we use the Toda and Yamamoto [21] and Hacker and Hatemi-J [22] methods based Toda-Yamamoto [21] linear Granger causality analysis in Table 5. Empirical test results show that there is no causality between budget deficits and inflation. These results of both procedures provide null hypothesis for these variables which are not rejected in Table 5.

Different from linear causality analysis, this procedure allows examining causality between these variables in different frequencies. We find no evidence of causal relationship running from budget deficits to inflation for all countries in Table 6.

Table 7 indicates that there is a permanent (long term) relationship for Belgium, France. This result shows unidirectional causality from inflation to budget deficits in these countries. By using this method, we do not find for the relationship running from inflation to budget deficits in medium and short term.

Table 4. Causality test results between budget deficits (BUD) and inflation rate (INF) based on HJC.

\begin{tabular}{|c|c|c|c|c|c|c|c|c|c|c|}
\hline \multirow{3}{*}{ Countries } & \multicolumn{5}{|c|}{$\mathrm{H}_{0}$ : BD does not Granger cause INF } & \multicolumn{5}{|c|}{$\mathrm{H}_{0}$ : INF does not Granger cause BD } \\
\hline & \multirow{2}{*}{ MWALD } & \multirow{2}{*}{$\begin{array}{c}\text { TY } \\
\text { Prob. }\end{array}$} & \multicolumn{3}{|c|}{ Bootstrap critical values } & \multirow{2}{*}{ MWALD } & \multirow{2}{*}{$\begin{array}{c}\text { TY } \\
\text { Prob. }\end{array}$} & \multicolumn{3}{|c|}{ Bootstrap critical values } \\
\hline & & & $1 \%$ & $5 \%$ & $10 \%$ & & & $1 \%$ & $5 \%$ & $10 \%$ \\
\hline Belgium & 0.183 & 0.913 & 9.674 & 6.083 & 4.673 & 0.243 & 0.886 & 10.343 & 6.373 & 4.801 \\
\hline Cyprus & 0.794 & 0.672 & 10.083 & 6.378 & 4.854 & 2.553 & 0.279 & 9.801 & 6.288 & 4.790 \\
\hline France & 0.566 & 0.753 & 10.414 & 6.361 & 4.776 & 0.182 & 0.913 & 9.304 & 6.121 & 4.592 \\
\hline Germany & 0.517 & 0.472 & 7.237 & 3.925 & 2.799 & 0.039 & 0.844 & 7.352 & 4.159 & 2.788 \\
\hline Netherlands & 0.907 & 0.341 & 7.891 & 3.927 & 2.649 & 0.029 & 0.865 & 7.903 & 3.865 & 2.637 \\
\hline Spain & 0.086 & 0.770 & 8.638 & 4.078 & 2.735 & 0.362 & 0.547 & 7.887 & 4.076 & 2.720 \\
\hline Sweden & 0.387 & 0.534 & 7.868 & 4.012 & 2.749 & 0.762 & 0.383 & 7.990 & 4.087 & 2.790 \\
\hline UK & 1.803 & 0.179 & 7.455 & 4.175 & 2.781 & 0.218 & 0.640 & 7.665 & 4.207 & 2.833 \\
\hline
\end{tabular}

Notes: In this table, INF signifies inflation rate and BD denotes budget deficits. It is used lags based on Hatemi-J Criterion (HJC). The notations ${ }^{* * *},{ }^{* *}$, and ${ }^{*}$ imply rejection of the null hypothesis at the $1 \%, 5 \%$ and $10 \%$ levels of significance, respectively. They based on the bootstrap critical values. TY probability is determined probability value by the Toda-Yamamoto procedure for the MWALD stat.

Table 5. Causality test results between budget deficits (BUD) and inflation rate (INF) based on HQC.

\begin{tabular}{|c|c|c|c|c|c|c|c|c|c|c|}
\hline \multirow{3}{*}{ Countries } & \multicolumn{5}{|c|}{$\mathrm{H}_{0}$ : BD does not Granger cause INF } & \multicolumn{5}{|c|}{$\mathrm{H}_{0}$ : INF does not Granger cause BD } \\
\hline & \multirow{2}{*}{ MWALD } & \multirow{2}{*}{$\begin{array}{c}\text { TY } \\
\text { Prob. }\end{array}$} & \multicolumn{3}{|c|}{ Bootstrap critical values } & \multirow{2}{*}{ MWALD } & \multirow{2}{*}{$\begin{array}{c}\text { TY } \\
\text { Prob. }\end{array}$} & \multicolumn{3}{|c|}{ Bootstrap critical values } \\
\hline & & & $1 \%$ & $5 \%$ & $10 \%$ & & & $1 \%$ & $5 \%$ & $10 \%$ \\
\hline Belgium & 1.273 & 0.736 & 12.442 & 8.068 & 6.439 & 5.398 & 0.145 & 12.177 & 8.259 & 6.535 \\
\hline Cyprus & 0.794 & 0.672 & 10.083 & 6.378 & 4.854 & 2.553 & 0.279 & 9.801 & 6.288 & 4.790 \\
\hline France & 0.566 & 0.753 & 10.414 & 6.361 & 4.776 & 0.182 & 0.913 & 9.304 & 6.121 & 4.592 \\
\hline Germany & 0.517 & 0.472 & 7.237 & 3.925 & 2.799 & 0.039 & 0.844 & 7.352 & 4.159 & 2.788 \\
\hline Netherlands & 0.907 & 0.341 & 7.891 & 3.927 & 2.649 & 0.029 & 0.865 & 7.903 & 3.865 & 2.637 \\
\hline Spain & 0.086 & 0.770 & 8.638 & 4.078 & 2.735 & 0.362 & 0.547 & 7.887 & 4.076 & 2.720 \\
\hline Sweden & 0.387 & 0.534 & 7.868 & 4.012 & 2.749 & 0.762 & 0.383 & 7.990 & 4.087 & 2.790 \\
\hline UK & 1.328 & 0.515 & 10.595 & 6.409 & 4.951 & 0.477 & 0.788 & 10.383 & 6.346 & 4.775 \\
\hline
\end{tabular}

Notes: In this table, INF signifies inflation rate and BD denotes budget deficits. It is used lags based on Hannan-Quinn Criteria (HQC). The notations ${ }^{* * * *},{ }^{* *}$, and ${ }^{*}$ imply rejection of the null hypothesis at the $1 \%, 5 \%$ and $10 \%$ levels of significance, respectively. They based on the bootstrap critical values. TY probability is determined probability value by the Toda-Yamamoto procedure for the MWALD stat.

${ }^{2}$ We also tested other information criteria named AIC and SIC, but we do not report them. Because HJC information criteria select the optimal lag order in VAR models, we can say that HJC criteria are more rational selection of lag length other criteria. Empirical results are found that there are no causal between the inflation and budget deficits. 
Table 6. Test results of frequency domain causality test: from BUD to INF.

\begin{tabular}{|c|c|c|c|c|c|c|c|}
\hline \multicolumn{8}{|c|}{ BD to INF causality } \\
\hline \multirow{2}{*}{\multicolumn{2}{|c|}{ Countries }} & \multicolumn{2}{|c|}{ Long term } & \multicolumn{2}{|c|}{ Medium term } & \multicolumn{2}{|c|}{ Short term } \\
\hline & & \multirow{2}{*}{$\begin{array}{c}\mathbf{0 . 0 1} \\
0.869\end{array}$} & \multirow{2}{*}{\begin{tabular}{|c|}
$\mathbf{0 . 0 5}$ \\
0.869
\end{tabular}} & \multirow{2}{*}{$\begin{array}{c}\mathbf{1 . 0 0} \\
0.741\end{array}$} & \multirow{2}{*}{$\begin{array}{c}\mathbf{1 . 5 0} \\
0.432\end{array}$} & \multirow{2}{*}{$\begin{array}{c}2.00 \\
0.327\end{array}$} & \multirow{2}{*}{$\begin{array}{l}\mathbf{2 . 5 0} \\
0.301\end{array}$} \\
\hline Belgium & $\omega_{i}$ & & & & & & \\
\hline Cyprus & $\omega_{i}$ & 0.876 & 0.878 & 1.229 & 0.826 & 0.411 & 0.251 \\
\hline France & $\omega_{i}$ & 0.322 & 0.323 & 0.777 & 0.642 & 0.538 & 0.491 \\
\hline Germany & $\omega_{i}$ & 0.493 & 0.492 & 0.130 & 0.171 & 0.504 & 0.748 \\
\hline Netherlands & $\omega_{i}$ & 0.074 & 0.077 & 2.021 & 2.034 & 1.990 & 1.965 \\
\hline Spain & $\omega_{i}$ & 1.135 & 1.144 & 5.849 & 5.511 & 5.025 & 4.788 \\
\hline Sweden & $\omega_{i}$ & 1.099 & 1.097 & 0.497 & 0.589 & 0.638 & 0.659 \\
\hline UK & $\omega_{i}$ & 2.356 & 2.361 & 2.512 & 1.957 & 1.749 & 1.672 \\
\hline
\end{tabular}

Notes: The lag lengths for the VAR models are determined by SIC. F-distribution with (2, T-2p) degrees of freedom equal 5.99. BD signifies budget deficits and INF denotes inflation rate. * Indicates the relationship of causality between these variables.

Table 7. Test results of frequency domain causality test: from INF to BUD.

\begin{tabular}{|c|c|c|c|c|c|c|c|}
\hline \multicolumn{8}{|c|}{ INF to BUD causality } \\
\hline \multirow{2}{*}{\multicolumn{2}{|c|}{ Countries }} & \multicolumn{2}{|c|}{ Long term } & \multicolumn{2}{|c|}{ Medium term } & \multicolumn{2}{|c|}{ Short term } \\
\hline & & \multirow{2}{*}{$\begin{array}{c}0.01 \\
7.062^{*}\end{array}$} & \multirow{2}{*}{$\begin{array}{c}0.05 \\
7.068^{*}\end{array}$} & \multirow{2}{*}{\begin{tabular}{|c|}
$\mathbf{1 . 0 0}$ \\
2.153
\end{tabular}} & \multirow{2}{*}{\begin{tabular}{|c|}
1.50 \\
0.853
\end{tabular}} & \multirow{2}{*}{$\begin{array}{c}2.00 \\
0.977\end{array}$} & \multirow{2}{*}{$\begin{array}{r}2.50 \\
1.098\end{array}$} \\
\hline Belgium & $\omega_{i}$ & & & & & & \\
\hline Cyprus & $\omega_{i}$ & 1.001 & 1.005 & 3.291 & 3.142 & 2.323 & 1.965 \\
\hline France & $\omega_{i}$ & $7.072^{*}$ & $7.074^{*}$ & 3.004 & 2.180 & 2.258 & 2.341 \\
\hline Germany & $\omega_{i}$ & 1.505 & 1.508 & 3.416 & 3.473 & 3.193 & 3.048 \\
\hline Netherlands & $\omega_{i}$ & 1.412 & 1.411 & 4.135 & 4.796 & 4.791 & 4.752 \\
\hline Spain & $\omega_{i}$ & 1.135 & 1.144 & 5.849 & 5.511 & 5.025 & 4.788 \\
\hline Sweden & $\omega_{i}$ & 3.524 & 3.512 & 0.142 & 1.127 & 1.733 & 1.996 \\
\hline UK & $\omega_{i}$ & 4.356 & 4.216 & 0.059 & 0.088 & 0.209 & 0.272 \\
\hline
\end{tabular}

Notes: The lag lengths for the VAR models are determined by SIC. F-distribution with (2, T-2p) degrees of freedom equal 5.99. BUD signifies current account deficits and INF denotes inflation rate. * Indicates the relationship of causality between these variables.

\section{Conclusion}

This paper is the first attempt to determine the relationship between the inflation and budget deficits for nine EU countries using different bootstrap causality and frequency domain causality tests. Empirical test results using bootstrap causality indicate that there is no causality between budget deficits and inflation in general. Further, frequency domain Granger causality analysis provides the evidence that the null hypothesis of no Granger causality running from budget deficit to inflation is accepted at $1 \%, 5 \%$ and $10 \%$ significance levels across all the frequencies. On the other hand, we find significant evidence of a long-term Granger causal relationship where results show unidirectional causality from inflation to budget deficits in Belgium, and France. We do not find for the relationship running from inflation to budget deficits in medium and short term. Finally, this paper can be extended by investigating the effect of public deficit problems on inflation and other macro-economic variables and may offer new insights for the problems.

\section{References}

[1] Sargent, T.J. and Wallace, N. (1988) Some Unpleasant Monetarist Arithmetic. Federal Reserve Bank of Minneapolis Quarterly Review, 5, 1-17. 
[2] Tanzi, V. (1978) Inflation, Real Tax Revenue, and the Case for Inflationary Finance: Theory with an Application to Argentina. Staff Papers-International Monetary Fund, 25, 417-451. http://dx.doi.org/10.2307/3866679

[3] Catao, L.A.V. and Terrones, M.E. (2005) Fiscal Deficits and Inflation. Journal of Monetary Economics, 52, 529-554. http://dx.doi.org/10.1016/j.jmoneco.2004.06.003

[4] Alesina, A. and Drazen, A. (1991) Why Are Stabilizations Delayed? The American Economic Review, 81, 1170-1188.

[5] Cukierman, A., Edwards, S. and Tabellini, G. (1992) Seigniorage and Political Instability. The American Economic Review, 82, 537-555.

[6] Jalil, A., Tariq, R. and Bibi, N. (2014) Fiscal Deficit and Inflation: New Evidences from Pakistan Using a Bounds Testing Approach. Economic Modelling, 37, 120-126. http://dx.doi.org/10.1016/j.econmod.2013.10.029

[7] Aiyagari, S.R. and Gertler, M. (1985) The Backing of Government Bonds and Monetarism. Journal of Monetary Economics, 16, 19-44. http://dx.doi.org/10.1016/0304-3932(85)90004-2

[8] Leeper, E.M. (1991) Equilibria under “Active” and "Passive” Monetary and Fiscal Policies. Journal of Monetary Economics, 27, 129-147. http://dx.doi.org/10.1016/0304-3932(91)90007-B

[9] Sims, C. (1994) A Simple Model for the Study on the Determination of the Price Level and the Interaction of Monetary and Fiscal Policy. Economic Theory, 4, 381-399. http://dx.doi.org/10.1007/BF01215378

[10] Woodford, M. (1994) Monetary Policy and Price Level Determinacy in a Cash-in-Advance Economy. Economic Theory, 4, 345-380. http://dx.doi.org/10.1007/BF01215377

[11] Woodford, M. (1995) Price Level Determinacy without Control of Monetary Aggregate. Carnegie-Rochester Conference Series on Public Policy, 43, 1-46. http://dx.doi.org/10.1016/0167-2231(95)90033-0

[12] Woodford, M. (2001) Fiscal Requirements for Price Stability. Journal of Money, Credit and Banking, 33, 669-728. http://dx.doi.org/10.2307/2673890

[13] Woodford, M. (1998) Doing without Money: Controlling Inflation in a Post-Monetary World. Review of Economic Dynamics, 1, 173-219. http://dx.doi.org/10.1006/redy.1997.0006

[14] Cochrane, J. (1999) A Frictionless View of US Inflation. In: Bernanke, B.S. and Rotemberg, J.J., Eds., NBER Macroeconomics Annual, MIT Press, Cambridge, 323-384.

[15] Cochrane, J.H. (2001) Long-Term Debt and Optimal Policy in the Fiscal Theory of the Price Level. Econometrica, 69, 69-116. http://dx.doi.org/10.1111/1468-0262.00179

[16] Dupor, B. (2000) Exchange Rates and the Fiscal Theory of the Price Level. Journal of Monetary Economics, 45, 613630. http://dx.doi.org/10.1016/S0304-3932(00)00006-4

[17] Bergin, P.R. (2000) Fiscal Solvency and Price Level Determination in a Monetary Union. Journal of Monetary Economics, 45, 37-53. http://dx.doi.org/10.1016/S0304-3932(99)00041-0

[18] Canzoneri, M.B., Cumby, R.E. and Diba, B.T. (2001) Fiscal Discipline and Exchange Rates Systems. Economic Journal, 111, 667-690. http://dx.doi.org/10.1111/1468-0297.00655

[19] Daniel, B.C. (2001) The Fiscal Theory of the Price Level in an Open Economy. Journal of Monetary Economics, 48, 293-308. http://dx.doi.org/10.1016/S0304-3932(01)00077-0

[20] Sims, C.A. (2001) Fiscal Consequences for Mexico of Adopting the Dollar. Journal of Money, Credit, and Banking, 33, 617-625. http://dx.doi.org/10.2307/2673918

[21] Toda, H.Y. and Yamamoto, T. (1995) Statistical Inference in Vector Auto Regressions with Possibly Integrated Processes. Journal of Econometrics, 66, 225-250. http://dx.doi.org/10.1016/0304-4076(94)01616-8

[22] Hacker, R.S. and Hatemi-J, A. (2006) Tests for Causality between Integrated Variables Using Asymptotic and Bootstrap Distributions: Theory and Application. Applied Economics, 38, 1489-1500. http://dx.doi.org/10.1080/00036840500405763

[23] Hannan, E.J. and Quinn, B.G. (1979) The Determination of the Order of an Autoregression. Journal of the Royal Statistical Society, 41, 190-195.

[24] Hatemi-J, A. (2003) A New Method to Choose Optimal Lag Order in Stable and stable VAR Models. Applied Economics Letters, 10, 135-137. http://dx.doi.org/10.1080/1350485022000041050

[25] Hamburger, M.J. and Zwick, B. (1981) Deficits, Money and Inflation. Journal of Monetary Economics, 7, $141-150$. http://dx.doi.org/10.1016/0304-3932(81)90057-X

[26] Dwyer, G.P. (1982) Inflation and Government Deficits. Economic Inquiry, 20, 315-329. http://dx.doi.org/10.1111/j.1465-7295.1982.tb00350.x

[27] Darrat, A.F. (1985) Inflation and Federal Budget Deficits: Some Empirical Results. Public Finance Review, 13, 206215. http://dx.doi.org/10.1177/109114218501300205 
[28] Ahking, F.W. and Miller, S.M. (1985) The Relationship between Government Deficits, Money Growth and Inflation. Journal of Macroeconomics, 7, 447-467. http://dx.doi.org/10.1016/0164-0704(85)90036-9

[29] King, R.G. and Plosser, C.I. (1985) Money, Deficits, and Inflation. Carnegie-Rochester Conference Series on Public Policy, 22, 147-195. http://dx.doi.org/10.1016/0167-2231(85)90031-4

[30] Giannaros, D.S. and Kolluri, B.R. (1986) Deficit Spending, Money, and Inflation: Some International Empirical Evidence. Journal of Macroeconomics, 7, 401-417. http://dx.doi.org/10.1016/0164-0704(85)90079-5

[31] Protopapadakis, A.A. and Siegel, J.J. (1987) Are Money Growth and Inflation Related to Government Deficits? Evidence from Ten Industrialized Economies. Journal of International Money and Finance, 6, 31-48. http://dx.doi.org/10.1016/0261-5606(87)90011-8

[32] Barnhart, S.W. and Darrat, A.F. (1988) Budget Deficits, Money Growth and Causality: Further OECD Evidence. Journal of International Money and Finance, 7, 231-242. http://dx.doi.org/10.1016/0261-5606(88)90018-6

[33] Ho, L.S. (1988) Government Deficit Financing and Stabilisation. Journal of Economic Studies, 15, 34-44. http://dx.doi.org/10.1108/eb002679

[34] Siddiqui, A. (1989) The Causal Relation between Money and Inflation in a Developing Economy. International Economic Journal, 3, 79-96. http://dx.doi.org/10.1080/10168738900080014

[35] Burdekin, R.C.K. and Wohar, M.E. (1990) Deficit Monetisation Output and Inflation in the United States, $1923-1982$. Journal of Economic Studies, 17, 50-63. http://dx.doi.org/10.1108/EUM0000000000149

[36] De Haan, J. and Zelhorst, D. (1990) The Impact of Government Deficits on Money Growth in Developing Countries. Journal of International Money and Finance, 9, 455-469. http://dx.doi.org/10.1016/0261-5606(90)90022-R

[37] Choudhary, M.A.S. and Parai, A.K. (1991) Budget Deficit and Inflation: The Peruvian Experience. Applied Economics, 23, 1117-1121. http://dx.doi.org/10.1080/00036849100000015

[38] Buiter, W.H. and Patel, U.R. (1992) Debt, Deficits, and Inflation: An Application to the Public Finances of India. Journal of Public Economics, 47, 171-205. http://dx.doi.org/10.1016/0047-2727(92)90047-J

[39] Dogas, D. (1992) Market Power in a Non-Monetarist Inflation Model for Greece. Applied Economics, 24, $367-378$. http://dx.doi.org/10.1080/00036849200000150

[40] Sowa, N.K. (1994) Fiscal Deficits, Output Growth and Inflation Targets in Ghana. World Development, 22, $1105-1117$. http://dx.doi.org/10.1016/0305-750X(94)90079-5

[41] Hondroyiannis, G. and Papapetrou, E. (1994) Cointegration Causality and Government Budget-Inflation Relationship in Greece. Applied Economic Letters, 1, 204-206. http://dx.doi.org/10.1080/135048594357880

[42] Metin, K. (1995) An Integrated Analysis of Turkish Inflation. Oxford Bulletin of Economics and Statistics, 57, 513-531. http://dx.doi.org/10.1111/j.1468-0084.1995.tb00037.x

[43] Metin, K. (1998) The Relationship between Inflation and the Budget Deficit in Turkey. Journal of Business \& Economic Statistics, 16, 412-422. http://dx.doi.org/10.2307/1392610

[44] Domac, I. and Yucel, E.M. (2005) What Triggers Inflation in Emerging Market Economies? Review of World Economics, 141, 141-164. http://dx.doi.org/10.1007/s10290-005-0019-7

[45] Lin, H.Y. and Chu, H.P. (2013) Are Fiscal Deficits Inflationary? Journal of International Money and Finance, 32, 214233. http://dx.doi.org/10.1016/j.jimonfin.2012.04.006

[46] Shabbir, T., Ahmed, A. and Ali, M.S. (1994) Islamabad Are Government Budget Deficits Inflationary? Evidence from Pakistan. The Pakistan Development Review, 33, 955-967.

[47] Karras, G. (1994) Macroeconomic Effects of Budget Deficits: Further International Evidence. Journal of International Money and Finance, 13, 190-210. http://dx.doi.org/10.1016/0261-5606(94)90015-9

[48] Cottarelli, C., Griffiths, M.E.L. and Moghadam, R. (1998) The Nonmonetary Determinants of Inflation: A Panel Data Study. IMF Working Paper, 98, 1-29. http://dx.doi.org/10.5089/9781451844016.001

[49] Komulainen, T. and Pirttila, J. (2002) Fiscal Explanations for Inflation: Any Evidence from Transition Economies? Economics of Planning, 35, 293-316. http://dx.doi.org/10.1023/A:1022491613255

[50] Neyapti, B. (2003) Budget Deficits and Inflation: The Roles of Central Bank Independence and Financial Market Development. Contemporary Economic Policy, 21, 458-475. http://dx.doi.org/10.1093/cep/byg025

[51] Tiwari, A.K., Tiwari, A.P. and Pandey, B. (2012) Fiscal Deficit and Inflation: What Causes What? The Case of India. Journal of International Business and Economy, 13, 57-81.

[52] Hatemi-J, A. and Morgan, B. (2009) An Empirical Analysis of the Informational Efficiency of Australian Equity Markets. Journal of Economic Studies, 36, 437-445. http://dx.doi.org/10.1108/01443580910992366

[53] Granger, C.W.J. (1969) Investigation Causal Relations by Econometric Models and Cross-Spectra Methods. Econometrica, 37, 424-438. http://dx.doi.org/10.2307/1912791 
[54] Geweke, J. (1982) Measurement of Linear Dependence and Feedback between Multiple Time Series. Journal of the American Statistical Association, 77, 304-313. http://dx.doi.org/10.1080/01621459.1982.10477803

[55] Breitung, J. and Candelon, B. (2006) Testing for Short and Long-Run Causality: A Frequency Domain Approach. Journal of Econometrics, 132, 363-378. http://dx.doi.org/10.1016/j.jeconom.2005.02.004

[56] Engle, R.F. and Granger, C.W.J. (1987) Co-Integration and Error Correction: Representation, Estimation, and Testing. Econometrica, 55, 251-276. http://dx.doi.org/10.2307/1913236

[57] Phillips, P.C.B. and Perron, P. (1988) Testing for a Unit Root in Time Series Regression. Biometrica, 75, 335-346. http://dx.doi.org/10.1093/biomet/75.2.335

[58] Kwiatkowski, D., Phillips, P.C.B., Schmidt, P. and Shin, Y. (1992) Testing the Null Hypothesis of Stationary against the Alternative of a Unit Root. Journal of Econometrics, 54, 59-178. http://dx.doi.org/10.1016/0304-4076(92)90104-Y 